\title{
The Impact of divorce on the main male character, Steve Miller, as reflected in Nicholas Sparks's the last song
}

\author{
Kusumaningrum ${ }^{\mathrm{a}, 1, *}$ \\ ${ }^{a}$ Litelature English Departement Ahmad Dahlan \\ ${ }^{1}$ kusumaningrum@com.uad.ac.id*; \\ * corresponding author
}

Article history

Received 01-09-2020

Revised 11-11-2020

Accepted 13-11-2020

Keywords

Psychological

Impact of Divorce

Divorce Father

\begin{abstract}
The Last Song written by Nicholas Sparks is a novel that tells about family conflict that begins from the divorce between the parents and involves their children. The children must face the reality about their parents' divorce when they are at the age of ten and seventeen. Not only for their children, but the divorce also brings an impact to the main male character, Steve Miller, in this novel. There is misunderstanding at the beginning in children's comprehension about the causes of the divorce in their family. But after they know, especially the daughter, everything has changed between the main male character and his children. The aims of this study are to analyze the cause of the divorce and the impact of divorce on male male character, Steve Miller, as reflected in Nicholas Sparks's The Last Song. The writer uses psychological approach to analyse the cause and the impact of the divorce on the main male character, Steve Miller, as reflected in Nicholas Sparks's The Last Song. The writer also uses qualitative research method. The primary data are taken from the copy of novel The Last Song (2010) in the form quotation, phrase, and clauses or in the form of sentences that are related to the points discussed in this research. While, the secondary data are taken from all the analysis and criticism related to the novel. This secondary data of this research are also taken from some library documents and internet sources. The result of this study shows that the cause of the divorce in Nicholas Sparks's The Last Song is because the male main character's wife had affair with the stranger that he does not know before. It makes the communication with his wife is rarely done. It also involves their children and makes the relationship between father and daughter is broken. Not only to the relationship between the family members, but this divorce also give effects to the main character's psychological and physical states.
\end{abstract}

This is an open access article under the CC-BY-SA license.

\section{Introduction}

The Last Song is one of the literary works that is written by Nicholas Sparks (Sparks, 2011). It is a piece of literature in fiction which deals about the story of the family's conflict. This novel has a good message about the affection towards our parents. Even though we are separate to our parents or not living together again because of the divorce, they are still our parents. Parents is a couple of person who give us a love, joy, kindness and everything that other person not necessarily can give us something like that. This novel also make the writer realize that everybody always has a second chances to make something better than before to fix the fault or everything that we make in past. The theme that appointed by Nicholas Sparks is also has an enjoyable love story which love is not always about the relationship between a girl and a boy, a boyfriend with his girlfriend, this novel gives us about the distinctive story about love. 
Based on the background of the story above, in this research, the writer will analyse the causes of the divorce in Nicholas Sparks's The Last Song first, to know what happens on the main male character's family, and afterwards the writer will focus on the impact that is caused by the divorce in Nicholas Spark's The Last Song through the main male character, SteveMiller. The aim of this study is to show that the divorce also can be impact toward the male side (Foti, Pauls, \& Rockmore, 2013).

\section{Theorotocal Framework}

In this chapter, the writer would like to explain about theories that will be used in this undergraduate thesis in analysing Nicholas Sparks's The Last Song. There are some theories that used in this research. They are psychological theory, psychological approach, divorce, and the impact divorce in the main male character.

\section{1) Psychological Theory}

According to Moghaddam in his article entitled From 'Psychology in Literature' to 'Psychology is Literature' An Exploration of Boundaries and Relationships (2000) that there are three reasons in valuable insight useful of psychologists that found in literature. The first reason is that a large body of great literature has explored long-term processes and change in persons and relationships over time, whereas most psychological research has focused on outcomes (rather that processes), tested in brief laboratory experiments, typically lasting an hour or so. Literary works could help psychologists gain a better understanding of long-term psychological processes and change, and in this way fill an important gap in psychological knowledge. This is in terms not only of individual personality development over the life-span, but also of the changing social relationships and collective and institutional processes that fundamentally shape individual development.

Second, there is a 'quality of mind' argument: great literature entails observations and ideas regarding human behaviour from some of the most brilliant minds in human history (B. Moghaddam \& Javitt, 2012).

A third argument is that these brilliant individuals have interests that in some ways are similar to those of modern psychologists; they raise questions that are similar and fundamental to understanding human behavior (K. S. Moghaddam, 2015).

2) Psychological Approach

To analyze this research, the writer uses psychological approach. Through the psychological approach, the personality and the character's behaviour in this story can be observed.According to K Smith in Literary Criticism Primer A Guide to the Critical Approaches to Literature that "The psychological approach in literature focuses on the motivation of the character" (p. 10). Meanwhile, Bernard J. Paris in his journal entitled Imagined Human Beings: A Psychological Approach to Character and Conflict in Literature stated that "When taking a psychological approach to literature, therefore, it is natural to focus on individual characters or type of characters (or anything that reflects human existence) and to examine character' behaviour, action, motivation, possessions, surroundings, personality traits, perception, imagination, interaction, conversations, relationships, and/or conflicts between characters and within characters, including inherent inconsistencies or contradictions. Observations are discovered and proved by doing a close reading/analysis and interpretation of the text (Horowitz, 2016).

\section{3) Divorce}

Divorces can be analyzed as events, that is, the decision to leave a partnership and the ending of marriage. However, they are often preceded by a long process of ending the relationship, which can include estrangement from the spouse, stress, conflicts, and even violence (Amato, 2010), and, as mentioned, the legal procedures dissolving the marriage may last well after both spouses consider the marriage ended. Thus, defining and measuring divorce -when it starts and when it ends -can be difficult. Despite the conflicts surrounding many divorces, many seemingly functional marriages end in divorce and on the other, not all troubled marriages break up (Härkönen, 2013). 
Divorce can be a very difficult change for anyone to deal with, especially children. It generally leads to the children not being able to see both parents every day, losing structure and stability in their life and needing to find ways to cope with all of these changes. (Ciattei, p. 2)

During most divorces, spouses who are also parents are faced with the fact that they must maintain some sort of contact with their ex because of their children. Depending on the type of relationship the two people had with each other, this could either lead to them having a positive or negative post-divorce relationship; this is known as the post-divorce co-parenting relationship (Sabo, Goodhew, \& Robertson, 2016). (cited in Ciattei: 3)

4) Impact Divorce in Father

In this theory the writer would like to discuss about the impact that is caused by the divorce on the main male character, Steve Miller. The process of the separation with his children and his family make him feels some experience that he already through while he separated. Seltzer (1991) found that just under half of divorced fathers (47\%) saw their children 1-3 times per month or more, and $25 \%$ saw their children at least weekly. Pasley \& Braver (2004) found that the context of families after divorce makes father involvement more difficult (Palkovitz \& Hull, 2018).

Non-residential parents (usually men) are particularly liked to experience negative effects of divorce. A pervasive problem is suffering caused by the feeling that they have lost their children, and feelings of inadequacy about their role as a parents (Dudley, 2008). They may also experience guilt about the martial break-up and the loss of daily contact with their children can be emotionally devastating for non-residential fathers (Hall, 2018).

Fathers felt that having children stay with them in their own homes helped them relax with each other and helped children know what fathers' lives were like. Fathers in the study reported that they could easily show affection to children. Almost all said they still cuddled their 8-year-olds. Despite the lack of everyday contact, fathers and children who remained in contact enjoyed warm relationships (Henriques, 2010).

The stress of divorce impacts emotional health as well. There is some evidence that suggests that men may be at greater risk for emotional disturbance, especially at the time of, and just following, the separation (Mayer, 2004). Divorced fathers are nine times more likely than married fathers to be admitted to psychiatric hospitals for the first than are men from intact families.

\section{Method}

In this undergraduate thesis, the writer uses qualitative research method. Qualitative research refers to the what, how, when, and where of a thing its essence and ambience. Thus refers to the meaning, concept, definitions, characteristics, metaphors, symbols, and descriptions of things. In contrast, quantitative research refers to counts and measure of things (Mauri \& Menon, 2017).

Qualitative data will be obtained primarily through some sources. Primary data will be taken from the copy of novel The Last Song (2010) in the form quotation, phrase, and clauses or in the form of sentence that are related to the points discussed in this research. Secondary data will be taken from all the analysis and criticism related to the novel The Last Song. This secondary data of this research are also taken from others sources such as some library document and internet source to help the writer in analysing the novel.

\section{Results and Discussion}

a) The Causes of the Divorce in Nicholas Sparks's The Last Song

In this part, the writer would like to describe about what happens on the main male character's family and explain the causes as well as the conflicts of the divorce in Nicholas Sparks's The Last Song. At the beginning, the Miller in The Last Song has been told as a happy family, that everything is going well. There is no conflict in this family. There is no gap and distance between the family members. They are living harmoniously. Especially is the relationship between Steve Miller as a father and Ronnie Miller as the daughter. They are very close to each other. Steve and his daughter are shared and doing everything together. Unfortunately, this condition does no longer exist. One 
day problem comes to this family. Steve as a father and husband faces a hard problem that imposes him to leave his family.

Steve as a husband and father leaves and decides to divorce his wife, Kim Miller because Kim had an affair with the stranger man that he does not know before who the man is. He found out it when he was walking around in the city. He looks Kim cheating with another man in a restaurant. However, Steve is not angry or scolded her directly. He chooses to observe his wife to know the truth. Like another couple who is being mad and shocked when they know their couple is cheating with another guy, Steve is also so shocked when he saw it. After he observed, the identity of the man who has love affair with Kim begins to reveal. She was seated at a small table wedged against the wall, across from a gray-haired man who appeared to be a few years older than her (Sparks, 2009: 404). It can be seen from the way the man touch and kiss her. Since that moment, Steve keeps silent. He does not ask Kim about her 'forbidden love'. Steve also does not tell his children about this condition. Steve tries to act normal. Even though it's difficult for him, he tries to keep going on with his life. Steve keeps this secret deeply only for himself. So, it has impacted to Steve's life. His thought is starting to mess up. His activity also began unbalanced. Everything that he does is not going well again. The relationship with Kim also becomes bad. Yet, Kim still does not know the reason why Steve is acting like that. Kim thinks that Steve is being like that, because he chooses to try his luck as a concert pianist, so it makes Steve is getting busy. Kim thinks that Steve prefers to choose his work rather than his family (Foti et al., 2013).

What Steve did is to leave his family and his decision to divorce his wife makes his relationship with Ronnie not good. It makes his daughter hate him. Steve's visit is not expected anymore by Ronnie. It just brings anger and some hated feeling from his daughter to him. Ronnie ignores his father, whenever he comes to New York and asks to meet with her. Steve came far away from North Caroline where he lived after he decided to divorce, he moved to North Carolina where his parents used to lived. Not only with Steve, but the relationship with her mother also is not going well. Ronnie is always arguing her mother. She always debates her mother in every chance. Divorce makes a happy family broken and bring some negative impacts towards the children. In this case, it changes Ronnie's behaviour.

From the analysis above, it can be concluded that children who were born in divorce's family or experience the divorce when they already grow up to adult is more difficult to accept the condition rather than the children who born in divorce's family when they are still a baby. It is because adult already knows about what the divorce is. They also know about the situation or the problem that they face. It makes them thinks that divorce is like burdens in their life. One of those burdens is about what people think. People have a negative opinion about children who born in the divorce family. However, some children who comes divorce family try to look for the causes of their parents' divorce. After they find the truth, they begin to judging their parents like the character Ronnie in The Last Song.

b) The Impact of Divorce on The Main Male Character, Steve Miller, in Nicholas Sparks's The Last Song

As noted earlier before that the aim of this study is to analyze the impact of divorce on the main male character, Steve Miller. Also as mentioned before in section A above that divorce makes the relationship and communication between Steve and his wife become bad and even it is involving their children. Not only for women, has the divorce also had an impact to the man side. This condition is reflectedon the main male character, Steve Miller, in Nicholas Sparks's The Last Song. After three years being separated (divorce) with his wife, the relationship between Steve and his daughter, Ronnie,is also getting worst. As a good father, Steve wants to keep in touch with his children, who are separated from Steve after he decided to divorce his wife. But then, his children avoid him, especially his daughter, Ronnie who always ignores him. Steve never gives up. He tries his best to get his children's heart back. Steve found the trouble to meet with his daughter. Ronnie hates her father. It makes Steve more difficult to engage himself in her daily life. It is a fortune that his wife can cooperate about sharing responsibility for parenting after divorce in Nicholas Sparks's The Last Song.

Even though, after the divorce, their children stay with Kim, she still permitted her husband to visit their children. So when she knew about bad relationship of his husband with Ronnie, Kim has a

Kusumaningrum (The Impact of divorce on the main male character, Steve Miller, as reflected in Nicholas Sparks's the last song) 
plan to fix the situation between them. Kim sends Ronnie to spend the summer with her father. That plan is successful, although at the beginning Ronnie's behaviour is not nice toward her father. She understood about Steve's feeling when Ronnie hates him. Kim believes that Steve still wants to take part in something daily activitywith his children after divorce and keep their attachment bonds. So, that is why Kim has initiative to send Ronnie to spend the rest of summer with his husband.

After the divorce, Steve realizes that his life is broken and shot to pieces. He also losses of his father role toward his beloved children. Divorce makes Steve difficult to communicate with them. It makes his heart empty. Steve regrets for what he has done in the past. It is reflected in his face when he moved from New York City to Wilmington, North Carolina where he'd grown up after the divorce happen in his life. In The Last Song, after the divorce, there is something that his children didn't know about what happen to their father. It is about his health. Steve has a stomach cancer. It has a long story about what Steve's cancer. He does not care with his illness. The thing that makes Steve stressed is because of the divorce. Actually his illness is already existed a long time before the divorce happen (Baumrin, 2012).

Additionally, Steve has a good way when he takes care of his children during the summer. He more thinks creatively and openly so that his children are comfortable with him. He approached them with thinking openly about what his children do neither in past or present. He always offers a help and asking permission before he get involve with his children's activity. He is kind of an affectionate person who never forces his children to do what he wants. Because of this, his children draw to Steve again. Especially is with Ronnie. It proves that Steve as the main male character and as a father for Ronnie in The Last Song never gives up to fix his bad relationship with his children after the divorce. He kept struggling and looking for the way to get his children's heart back, so that they can keep in touch each other and never break the father and daughter's bond after the divorce.

Despite the lack of everyday contact, fathers and children who remained in contact enjoyed warm relationships, such as those in The Last Song that Steve as the main male character and as a father, Steve also reflects that he feels relax and happier with the presence of his children. They enjoyed their time together while make beautiful memories with the limited time that Steve have after they know Steve's disease. And there is a moment in the last minute before Steve died that make Steve pleased in addition to the reason of the presence of his children that is the song that finished by his daughter.

\section{Conclusion}

This chapter contains the conclusion of this research. There are two problems formulation of this research. The first is the causes of the divorce in Nicholas Sparks's The Last Song, and the second is the impact of divorce on the main male character, Steve Miller, in this novel.

From the analysis of this research, the writer finds out that the divorce in The Last Song is caused by the third person who indirectly ruins the marriage life of Steve and Kim. It makes the main male character's life upside down. The communication between him and his wife becomes bad. He looses the role of father in his life and makes the relationship between him and his daughter break. Steve's daughter in this novel also shows that divorce is something that is difficult to deal for children.

From this research, the writer also wants to show that divorce also has an impact for the male side. The writer finds out that the impact of divorce makes the main male character in The Last Song difficult to communicate with his daughter. In addition, the divorce also gives some effect to his psychological state. It makes his heart and life feels empty. He also gets stomach cancer. Furthermore, there is change of his personality who becomes more open-minded about what his children do neither in past or present. 


\section{References}

Amato, P. R. (2010). Research on divorce: Continuing trends and new developments. Journal of Marriage and Family. https://doi.org/10.1111/j.1741-3737.2010.00723.x

Baumrin, B. (2012). Divorce. In Encyclopedia of Applied Ethics. https://doi.org/10.1016/B978-0-12-3739322.00256-8

Dudley, N. (2008). Guidelines for applying protected area management categories. In Guidelines for applying protected area management categories. https://doi.org/10.2305/iucn.ch.2008.paps.2.en

Foti, N. J., Pauls, S., \& Rockmore, D. N. (2013). Stability of the World Trade Web over time - an extinction analysis. Journal of Economic Dynamics and Control. https://doi.org/10.1016/j.jedc.2013.04.009

Hall, R. (2018). A new interpretation of Java's structure. https://doi.org/10.29118/ipa.1077.07.g.035

Härkönen, U. (2013). Reorientation of teacher education towards sustainability through theory and practice. In Proceedings of the 10th international JTEFS/ BBCC conference Sustainable development. Culture. Education.

Henriques, S. T. (2010). Lund university. Ecology.

Horowitz, C. A. (2016). Paris Agreement. International Legal Materials. https://doi.org/10.1017/s0020782900004253

Mauri, C., \& Menon, M. (2017). Human regulatory B cells in health and disease: Therapeutic potential. Journal of Clinical Investigation. https://doi.org/10.1172/JCI85113

Mayer, R. E. (2004). Should There Be a Three-Strikes Rule Against Pure Discovery Learning? American Psychologist. https://doi.org/10.1037/0003-066x.59.1.14

Moghaddam, B., \& Javitt, D. (2012). From revolution to evolution: The glutamate hypothesis of schizophrenia and its implication for treatment. Neuropsychopharmacology. https://doi.org/10.1038/npp.2011.181

Moghaddam, K. S. (2015). Fuzzy multi-objective model for supplier selection and order allocation in reverse logistics systems under supply and demand uncertainty. Expert Systems with Applications. https://doi.org/10.1016/j.eswa.2015.02.010

Palkovitz, R., \& Hull, J. (2018). Toward a Resource Theory of Fathering. Journal of Family Theory and Review. https://doi.org/10.1111/jftr.12239

Sabo, H. C., Goodhew, L. M., \& Robertson, A. D. (2016). University student conceptual resources for understanding energy. Physical Review Physics Education Research. https://doi.org/10.1103/PhysRevPhysEducRes.12.010126

Sparks, N. H. C. (2011). Eggshell pigments - From formation to deposition. Avian Biology Research. https://doi.org/10.3184/175815511X13228269481875 